\title{
Options for Soil Health Measurement in Vineyards and Deciduous Fruit Orchards, with Special Reference to Nematodes
}

\author{
C. Kapp ${ }^{1, *}$, S.G. Storey ${ }^{2}$ and A.P. Malan ${ }^{1}$ \\ (1) Department of Conservation Ecology and Entomology, Stellenbosch University, Stellenbosch, South Africa \\ (2) Nemlab, c/o R44 and Anyswortelrug road, Stellenbosch, South Africa
}

Submitted for publication: May 2013

Accepted for publication: July 2013

Key words: Soil health, bio-indicator, nematode, sustainability

\begin{abstract}
Soil is a non-renewable resource and supports all land-based forms of life. The sustainable production of crops is becoming progressively more critical as human populations increase and viable agricultural land decreases. Soil health plays an indispensable part in the sustainability of soil as a resource for future generations. For this very reason it is important to have suitable tools to measure the improvement or deterioration of soil health in vineyards and orchards. In this review, the use of different bio-indicators to indicate soil health will be discussed, with special emphasis on the use of nematode population structure and function as indicators of soil health. The use of nematodes as a bio-indicator of soil health can play a crucial role in the establishment of future sustainable production of grapes and fruit in the Western Cape. This paper provides a comprehensive review of soil health, the use of different biological indicators, and the potential of nematodes as suitable indicators thereof, aimed at vineyards and deciduous fruit orchards.
\end{abstract}

\section{INTRODUCTION}

The narrow soil stratum covering the earth's surface is, in one way or another, responsible for the continuing existence of all land-based life forms. Natural processes that uphold the global ecosphere and, essentially, life on earth are under grave threat due to environmental degradation, social volatility, diminishing resources and escalating human populations (Doran \& Safley, 1997). Modern agriculture is facing the pressing situation where strategies have to be devised to preserve soil as a non-renewable resource. The utilisation of these non-renewable resources, such as agricultural soil, has to be improved, with the processes concerned needing to be in harmony with those biological processes that maintain the existence of life on earth. The strategies in question have to maintain the long-term sustainability of agriculture by eternalising ecological principles (Doran \& Safley, 1997).

The concept of soil health, which is becoming more widely used within agricultural circles, can be utilised as a tool to educate producers, especially regarding several of the less apparent possibilities of soil degradation due to inadequate management practices. The education process, in turn, will lead to the promotion of more sustainable farming practices. The good health of agricultural soil is the key to the production of healthy food for generations to come.

In order to sustain crop production in the long term, soil must perform certain functions. These functions include the infiltration and storage of water, the recycling and retention of nutrients, the suppression of weeds and pests, the detoxification of damaging chemicals, the sequestering of carbon and, lastly, the production of food and fibre (Gugino et al., 2009). The disposable income, as well as the sustainable production, of a farm is ultimately at risk if the soil does not function optimally due to soil constraints existing for a period of time. Improving and maintaining the health of the soil have vast economic benefits for agriculture. Such benefits include improved plant growth, reduced risk of yield loss, and reduced input costs due to the decreased amount of tillage required, and the reduction in fertiliser, pesticide and herbicide requirements (Gugino et al., 2009).

Healthy soils are an economic and natural asset, as they support sustainable farming practices as well as the production of various minerals. Healthy soils contribute to environmental health, can aid in enhancing the condition of water resources, sustain soil-borne organisms, incorporate and integrate waste products, and store carbon.

\footnotetext{
What is soil health?

The term 'soil health' has become increasingly popular since the mid-1990s (Nielsen \& Winding, 2002), even though the concept itself is not new. The significance of soil health for agricultural affluence was already acknowledged more than 2000 years ago by Roman and Greek philosophers. The necessity for a clear definition of soil health became apparent when it was realised that the terms 'soil health' and 'soil quality' have essentially been regarded as synonyms by many previous researchers.
} 
Soil health is defined as "the continued capacity of soil to function as a vital living system, within ecosystem and landuse boundaries, to sustain biological productivity, maintain the quality of air and water environments, and promote plant, animal and human health" (Doran et al., 1996). Rather than depicting soil as an inanimate mixture of sand, silt and clay, soil health provokes the impression of soil being a dynamic, living organism that functions holistically and that is essentially dependent on ecological characteristics (Van Bruggen \& Semenov, 2000). Soil quality relies more on the use of the quantitative characteristics of soil, namely the physical, chemical and biological qualities thereof (Doran et al., 1996).

According to Gugino et al. (2009), the authors of the Cornell Soil Health Assessment Training Manual, the characteristics of a healthy soil are as follows: "A healthy soil has good soil tilth (which is the overall physical characteristics of the soil when seen in perspective of its suitability for crop production); sufficient depth to enable sufficient root growth; sufficient but not excess supply of nutrients; small populations of plant pathogens and insect pests; good soil drainage; low weed pressure; large population of beneficial organisms; resistance to degradation; resilience to unfavourable conditions; soil that is free of chemicals and toxins that may harm the crop."

Within the South African fruit-producing industry, pressure exists for the sustainable production of high-quality fruit to satisfy our local and export markets. Such pressure has prompted great interest in soil health, which is bound also to promote sound production management practices, which, in turn, will serve to enhance soil characteristics. The interest expressed has prompted research in South Africa to be focused on the use of mulches and biological control agents to enhance soil health, within integrated pest management systems.

Overall, however, a major problem is how to measure soil health. The ultimate bio-indicator for soil health should consistently indicate problems that are present within the soil, should work with uniform efficiency in all environments, and should be capable of being measured simply (Elliot, 1997). Bio-indicators should preferably not only indicate problems within the environment after the fact, but also be able to predict forthcoming problems, or shortcomings, within the soil environment.

\section{Bio-indicators used to indicate soil health}

In some measure, the condition of an ecosystem can be described by soil bio-indicators, which are essentially biological properties or processes within the soil fraction of any given ecosystem. According to Elliot (1997), soil health can never be proved, but only the lack of measurable disease. Time plays an important factor in the establishment of the health of a system. When a system has been functioning normally for a reasonable period of time, it can be deduced that the system is healthy, and, alternatively, if a fault has been perceived, it can be deduced that the system is unhealthy.

A whole host of different components within the soil affect its health, thus it is improbable that a single measurement can be implemented to measure the soil ecosystem's health. For the reason specified, the research that has been conducted ranges from the impact of heavy-metal contamination on microbial biomass and activity (Angle et al., 1993; Brendecke et al., 1993; Chander \& Brookes, 1993; Yeates et al., 1994; Speir et al., 1995; Valsecchi et al., 1995; Frostegård et al., 1996) to the responses of soil microbial organisms to pesticides (Harden et al., 1993) and industrially contaminated soils (Rowell \& Florence, 1993). Key processes and components are used mainly to formulate measures that are symptomatic of disease. Extrapolation of the measures to systems that are known to be dysfunctional can be implemented to determine their effectiveness as measures of disease (Elliot, 1997).

Microorganisms in the soil are composed of microfauna and are defined as microscopic interstitial animals living in the soil, while microflora can be defined as bacteria and microscopic algae and fungi, especially those living in a particular site or habitat (Weiner \& Simpson, 1989). In the current study, mesofauna are defined as nematodes, protozoa, mites and small-sized Collembola (Gupta \& Yeates, 1997), while macrofauna are defined as animals that are large enough to be seen with the naked eye (Doube \& Schmidt, 1997). Potential soil health indicators are discussed below.

\section{Microbial biomass, activity and nutrient cycling}

In order for any soil to function normally and healthily, an immense number of microorganisms, which naturally inhabit and execute an extensive array of essential activities in the soil, are needed. Microbes within the soil are responsible for the decomposition of organic matter, for the degradation of toxic residues and for the release of nutrients in plant-available forms. In addition, soil microbes function as adversaries to pathogens, establish symbiotic relationships with plant roots, play a role in the agglomeration and composition of soil, and encourage the solubilisation and deterioration of minerals (Sparling, 1997). The role that microbes perform in soil processes, in addition to maintaining a moderately elevated rate of turnover ( 0.2 to six years) regarding microbial metabolism, indicate that the microbial fraction could be a conceivable and responsive indicator, as well as an initial predictor of changes within processes concerning soil organic matter (Powlson \& Jenkinson, 1981; Powlson et al., 1987).

Soil microbial respiration (Anderson, 1982; Insam, 1990) and the microbial biomass (determined by biochemical methods) are the two microbial indices that have been proposed (Jenkinson \& Ladd, 1981; Sparling \& Ross, 1993; Martens, 1995). Microbial mineralisation of soil organic nitrogen is already deemed an example of a nutrient alteration procedure that is being applied as an index of soil health (Sparling, 1997). The Cornell Soil Health Assessment Training Manual promotes the implementation of potentially mineralisable nitrogen, expressed as $\mu \mathrm{g}$ nitrogen mineralized per gram dry weight of soil per week ( $\mu \mathrm{g} \mathrm{N} / \mathrm{gdwsoil} /$ week), as a biological indicator of soil health (Gugino et al., 2009).

The absolute microbial biomass content of a soil has only provided a significant measurement of soil health in a few cases. Conflicting trends in relation to soil fertility and plant production, as well as the natural array of microbial biomass contents within diverse soil types, are known to impede interpretation. An additional problem is the absence 
of reference values. Sparling (1997) stated that no clear activation points have been identified either above or below which microbial biomass indices could serve as a reasonable indicator of the relative state of health of a soil. Alternatively, soil microbial biomass can provide a more sensitive measure of change and can demonstrate trends over different periods, although a reference soil of a similar type is required, as well as a specific minimum data set for specific end points (Nielsen \& Winding, 2002). It has been revealed that the BIOLOG ${ }^{\mathrm{TM}}$ assay is more responsive to the impacts of sewage sludge amendments to soil and soil management practices than respiration measurements and microbial biomass (Bending et al., 2000; Burgess et al., 2001; Nielsen \& Winding, 2002).

The mineralisation of nitrogen $(\mathrm{N})$ from soil organic matter can supply a valuable incorporation of biological, physical and chemical facets of soil health, since it combines both the accumulation of $\mathrm{N}$ through previous activities and the current $\mathrm{N}$ mineralisation activity of soil microorganisms (Sparling, 1997).

\section{Soil enzyme activities}

Soil-inhabiting microorganisms and fauna are key instruments for countless processes transpiring within the soil. As reported by Dick (1997), soil enzymes are the intermediaries and catalysts of significant functions in the soil. Dick proposed that the evaluation of enzymes in soils could possibly offer an integrative index for the biological status of a soil, or for the ability of a soil to perform unobtrusive, enzyme-catalysed processes.

In the past two to three decades, progress has been made in the advancement of techniques aimed at measuring the activity of more than 50 enzymes found in the soil. Various enzymes, which are substrate specific, can also be selected from assorted functional groupings, allowing for the prospect of determining the potential of a soil to perform an entire range of reactions that might be critical for the functioning of an ecosystem. Enzyme activity could also possibly be implemented to determine whether a degraded or stressed soil is too weakened to perform particular biochemical processes (Dick, 1997).

Dick (1997) also states that soil enzyme activities have not been found to correlate consistently with crop productivity in an agro-ecosystem. In addition, choosing the right enzyme bioassay is of vital importance. Only when a reference value is available for comparison can soil enzyme activities be utilised successfully to identify a wide range of soil management practices (Pankhurst et al., 1997). The calibration of soil enzyme activities is essential across an extensive range of soil types, ecosystems and soil management practices. The development of relative soil enzyme indices that are easily interpreted and that are similarly independent of soil type and environment is also needed (Pankhurst et al., 1997).

\section{Soil microflora}

Fungi, algae, actinomycetes and bacteria form part of the assemblage of microorganisms within a soil environment. These soil microflora potentially possess the capability to be utilised as important indicators of soil health (Van Bruggen \& Semenov, 2000). Practically all nitrogen and carbon conversions that take place within the soil environment, as well as the decomposition and modification of organic matter, can be ascribed to microorganisms (Alexander, 1977; Apsimon et al., 1990). By means of the decomposition of carbon compounds by such organisms, energy is supplied to heterotrophic microorganisms, which, in turn, are responsible for other nutrient transformations.

The transformation of a considerable amount of minerals within soil is dependent on microorganisms. All the processes performed by the organisms affect the availability of nutrients within the soil environment, which ultimately influences the health and quality of the soil concerned. The microbial fraction plays a crucial role in the functioning of an ecosystem. Consequently, in addition to being a practical tool for determining instability and disruptions in the ecosystem, it potentially can serve as a sensitive biological marker (Turco et al., 1994).

One of the problems with the use of microflora as an indicator of soil health is the poor cultivability of most organisms concerned (Pankhurst et al., 1997). Many such organisms have also not yet been identified (Roper \& Ophel-Keller, 1997). Spatial and temporal heterogeneity also make it practically impossible to use absolute values of microfloral populations or processes as direct bio-indicators of soil health. For the measuring of the impact of chemical pollution on soils, changes in microbial populations and changes within specific functional groups have been utilised. The development of new techniques, such as DNA and GC-FAME techniques, to measure the structural as well as functional diversity of microbial communities will offer innovative, and mostly novel, components for applying microorganisms as bio-indicators (Pankhurst et al., 1997).

\section{Plant root pathogens}

Elevated levels of soil-borne plant pathogens are considered to be an indication of reduced soil health (Pankhurst, 1994). In all probability, the reason for such a presumption is the possibility or threat of disease. A root pathogen thus is an indicator of the problem for which a specific pathogen is the cause. According to Hornby and Bateman (1997), in such instances the bio-indicator would also be an organism requiring suppression. The presence of a root pathogen does not automatically imply an environmental problem that could cause a decline in the health of the soil concerned, but its presence does indicate the existence of disease in the affected soil.

The occurrence of root pathogens in soil is more of an indication of a problem with certain host plants, rather than being the cause of poor soil health that could negatively influence the majority of organisms present (Hornby \& Bateman, 1997). Root pathogens are not regarded as bioindicators of soil health (Pankhurst et al., 1997).

\section{Soil mesofauna}

Nematodes, protozoa, mites and small-sized Collembola form part of the group of organisms within the soil mesofauna (Swift et al., 1979). Mesofauna form a crucial link between the primary decomposers (specifically microflora) and the larger macrofauna in the detritus food web within the soil. Nutrients that are immobilised by soil microflora are released by the mesofauna, which act as the primary agents in the overall process (Gupta \& Yeates, 1997). 
Mesofauna are implicated in an assortment of ecosystems (Stout \& Heal, 1967; Yeates, 1981; Freckman \& Caswell, 1985; Old, 1986; Gupta \& Germida, 1989; Henkinet et al., 1990; Darbyshire, 1994). The nutrient uptake of plants may be directly or indirectly influenced by nematodes in terms of their effect on plant health. Such effects include plantparasitic nematodes feeding on the roots of their host plants (Norton, 1978), and symbiotic bacteria (e.g. mycorrhizae and rhizobia) (Westcott \& Barker, 1976) serving as a source of food for free-living nematodes (Hussey \& Roncadori, 1981), as well as biocontrol bacteria (Bird \& Ryder, 1993) and other microflora, such as plant-pathogenic bacteria (Chantanao \& Jensen, 1969; Freckman \& Caswell, 1985).

Soil mesofauna, especially nematodes and protozoa, are generally very adaptable within their environment to the health and condition of the soil that they inhabit (Gupta \& Yeates, 1997). Such organisms conform to the general characteristics required of a bio-indicator, as indicated by Elliot (1997). Nematodes and protozoa, which are omnipresent, abundant and diverse within soil ecosystems, have various measurable qualities and are closely involved in the regulation of decomposition, as well as in plant nutrient cycling, which makes them prospective bio-indicators (Gupta \& Yeates, 1997). Because their enumeration in soils is significantly influenced by spatial and temporal variability, serious consideration must be given during sampling to ensure that the soil samples are representative of the entire system.

One of the most useful attributes of the above-mentioned organisms is trophic diversity, as such diversity is directly influenced by the food sources that are available in the soil (Gupta \& Yeates, 1997; Pankhurst et al., 1997).

\section{Soil arthropod community structures}

Collembola, mites, Oribatida, Isopoda and Diplopoda are examples of soil arthropods. These micro-arthropods have complex associations with their niches in the soil, thus their community structures could be exploited as bio-indicators of soil health. The above-mentioned soil arthropods are very inactive organisms and consequently tend to reveal the condition of a native habitat better than do other insects with a high dispersal rate (Van Straalen, 1997).

The soil ecological research group at the Staatliches Museum für Naturkunde, Karlsruhe, conducted a study in which the soil fauna from 11 different forest sites were examined in order to establish a system of soil quality, based on biological criteria (Ruf, 1998). As part of the study, the incidence of predatory mesostigmatid mites was studied to test whether a maturity index for such mites (Mesostigmata: Gamasina) could be used as an indicator of the environmental impact of pollution on soils in a forest. Predatory soil mites appear to be a good indicator only when their life history traits are taken into consideration.

The distribution of Collembola and mite species has been used effectively as an indicator of soil health in a number of studies. Their distribution has been especially accurate in studies related to soil $\mathrm{pH}$ (Van Straalen \& Verhoef, 1997), soil carbon/nitrogen (C/N) ratio and heavymetal contamination of soils (Bengtsson \& Tranvik, 1989). Single species analysis is a less useful soil health indicator than is community composition analysis (Dick, 1997; Gupta
\& Yeates, 1997; Pankhurst et al., 1997).

Collembola or springtails are some of the most plentiful arthropods within temperate cultivable farmland. Framptom (1999) investigated the effects of the insecticides pirimicarb, chlorpyrifos and cypermethrin on Collembola in winter wheat. Collembola were found to be susceptible to organophosphate insecticides, but not to cypermethrin, which limits their use as indicators of pesticide usage. An additional undesired characteristic of Collembola is their spatial variability (Framptom, 1999).

\section{Abundance and activity of soil macrofauna}

The soil macrofauna fragment is defined as organisms that are larger than $2 \mathrm{~mm}$. They are visible to the naked eye and comprise ants, amphipods, termites, centipedes, isopods, millipedes, earthworms, enchytraeid worms, slugs, snails, and adult plus larval stages of root-feeding insects (Doube $\&$ Schmidt, 1997). They redistribute organic residues and, in doing so, increase the extent of microbial activity. This, in turn, enhances nutrient availability throughout the whole root zone and the decomposition of organic matter, which results in improved soil structure (Linden et al., 1994). Of the macrofauna, earthworms were identified as being best suited as a potential bio-indicator.

Earthworms influence an infinite assortment of chemical, physical and biological factors in the soil environment (Doube \& Schmidt, 1997). Through such factors, they increase plant growth in tropical (Tian et al., 1993; Kang et al., 1994) and temperate (Lee, 1985; Hendrix, 1995; Edwards \& Bohlen, 1996) environments. Earthworms, however, are not ubiquitous and do not always respond consistently to treatments (Doube \& Schmidt, 1997; Neher, 2001). Their abundance also varies greatly with climate and soil type. A number of studies have indicated that earthworms offer only limited potential to act as a bio-indicator of soil health (Samoiloff, 1987; Freckman, 1988; Doran et al., 1996), although they have greater potential for use as bioaccumulators of environmental contaminants (Pankhurst et al., 1997).

\section{Nematode communities as bio-indicators of soil health}

Within the boundaries of using soil mesofauna as bioindicators, three different groups of mesofauna, namely Collembola (Framptom, 1999), mites (Ruf, 1998) and nematodes (Neher, 2001), have been measured for their potential use as biological indicators of soil health. Nematodes (both plant parasitic and free living) have been assessed most frequently for their use as indicators and are amongst the simplest metazoa (Bongers \& Ferris, 1999). The organisms concerned have been determined as the most practical group for community indicator analysis, since information regarding their feeding behaviour and taxonomy is easily obtained.

Nematodes are advantageous as ecological and biological indicators because they possess numerous useful characteristics. Soil nematodes inhabit a fundamental position in the detritus food web, and can be placed in at least five trophic or functional groups (Neher, 2001). They also feed on most soil organisms and are also a food source for many other organisms. Nematodes are omnipresent in all soil environments that provide a supply of organic carbon. 
Some species are able to outlive all other animal species in disturbed or polluted environments (Bongers, 1990; Yeates et al., 1993; Ferris \& Bongers, 2001; Yeates, 2003). They occur in habitats that vary from highly polluted to unspoiled, in all types of soils and under any climatic conditions.

Nematodes have diverse feeding behaviours and life strategies, ranging from colonisers to persisters (Bongers \& Ferris, 1999; Ritz \& Trudgill, 1999). Predominantly, morphological structures correlated with diverse feeding behaviours are used to separate and classify nematodes. Nematodes can be identified without implementing biochemical procedures. Since they are transparent, it is possible to distinguish their internal morphological characteristics.

The sampling and extraction of nematodes from soil samples are relatively simple and are more cost effective than the techniques that are employed to extract other soil organisms, due to the size and relative profusion of the former (Neher, 2001). The structure and function of the nematode mouth cavity and oesophagus make it possible to deduce their feeding behaviour easily (Yeates \& Coleman, 1982; Freckman, 1988; Bongers \& Ferris, 1999). Nematodes control nutrient mineralisation and the degree of decomposition by influencing the growth and metabolic activities of microbes and by regulating the behaviour of the microbial community (Neher, 2001). Nematodes have been established to perform a direct role in the distribution of biomass within plants and in nitrogen mineralisation.

The utilisation of nematodes as bio-indicators is reinforced by many of their biological characteristics. Their permeable cuticle allows them to react with a wide range of responses to changes in the environment (e.g. pollutants), since they are in immediate contact with their micro-environment. Furthermore, nematodes react speedily to any enrichment and disturbance, leading to an increase in microbial activity, which sequentially will cause changes in the proportion of bacterial feeders in a community (Bongers \& Ferris, 1999).

When environmental conditions are unfavourable for development and growth, certain species of nematodes experience resistant stages, such as cyst formation, cryptobiosis and anhydrobiosis, which allow them to survive inactively (Neher, 2001). Many species can also survive oxygen stress, freezing and dehydration (Bongers \& Ferris, 1999). Within the soil horizon that is inhabited by nematodes, the condition of the soil is indicated by the nematode community structure.

Nematodes also possess highly conserved heat shock proteins (Hashmi et al., 1997). When nematodes are exposed to stresses (such as organic toxins, heat or metal ions) the expression of such proteins is enhanced (Kammenga et al., 1998; Neher, 2001). The proteins concerned also have the potential to function as biomarkers during eco-toxicological evaluations of soils (Guven et al., 1994, 1999; Kammenga et al., 2000).

\section{Indices used for the analysis of nematode assemblages Diversity indices}

Numerous indices have been developed and utilised to assess the biodiversity of ecosystems. The indices that are used for soil nematodes are not applied to the ecosystem in absolute terms, but are applied to numbers of taxa. Community diversity can be computed at three levels of certitude: 1) diversity founded on the profusion of individuals within each genus/group; 2) trophic diversity, founded on the profusion of individuals within each trophic group or family; and 3 ) the diversity of genera within each family, which is a form of trophic richness. The relative abundance and evenness of the occurrence of nematode trophic groups is described by means of trophic diversity indices (Ferris \& Bongers, 2009).

Diversity indices that are useful for nematodes as bioindicators of soil health (Ferris \& Bongers, 2009) include: Shannon's diversity index (H') (Shannon \& Weaver, 1949); species richness (S), which is also referred to as Hill's $\mathrm{N}_{0}$ index (Hill, 1973); Simpson's diversity index (D) (Simpson, 1951); Hill's N index (Hill, 1973); Hill's $N_{2}$ index (Hill, 1973); and Pielou's J' evenness index (Pielou, 1966).

\section{Indices of ecosystem function Cp values}

The coloniser-persister (cp) scale or series is the assignment of taxa of soil and freshwater nematodes to a 1 to 5 linear scale according to their $r$ (opportunists) and $K$ (competitor) characteristics (Ferris \& Bongers, 2001). The series can vary from extreme $r$ to extreme $K$ strategists (Ferris \& Bongers, 2009). Resource availability is denoted by coloniser nematodes, which are regarded as enrichment opportunists, at the lower end of the $\mathrm{cp}$ scale. Food web complexity and connectance, as well as system stability, are revealed by persister nematodes at the high end of the cp scale.

Bongers (1990) introduced cp scaling, which presents the life-history ordinate for the functional guild matrix of nematodes, with the abscissa being provided by known or inferred feeding habits (Ferris \& Bongers, 2006). An individual nematode taxon, especially at family level, is grouped into one of the five cp classes (Ferris \& Bongers, 2009). The same cp value that is assigned to the family is assigned to genera and species within a taxon. For this reason, identifying nematodes to genera and species level for the purpose of the current study is superfluous. As reported by Ferris and Bongers (2009), the relevance of family-level assignments has been justified on the basis that nematodes with similar life history traits have a high probability of having similar sensitivity and responsiveness to environmental change. Bongers and Bongers (1998) provided the most recent descriptions of the $\mathrm{cp}$ assignments for terrestrial nematode families.

\section{Maturity index (MI)}

The coloniser-persister scale described in the previous section forms the basis for the maturity index (MI). Quintessentially, the $\mathrm{MI}$ is an ecological indicator of the condition of progression of a system by means of which disturbance, and its resulting enrichment responses, result in an impediment to succession to an earlier state (Odum, 1985). The MI is defined as the weighted mean of the individual $\mathrm{cp}$ values for the nematodes in a sample and, in practice, varies from 1, under conditions of extreme enrichment (such as in cow pats or following heavy maturing), to a value of 3 or 4 under 
undisturbed conditions (Bongers \& Bongers, 1998; Bongers \& Ferris, 1999). The nematode MI, which is one of the key indices of soil health, is regarded as a gauge for environmental disturbance and is based on non-plant feeding taxa (Bongers \& Ferris, 1999), meaning that plant-parasitic nematodes, as listed by Bongers (1990), are excluded. Entomopathogenic nematodes, animal parasites and dauer larvae of enrichment opportunists are also not included in the calculation of the MI. Their exclusion from the calculation is due to the fact that the incidence of the previously mentioned nematodes within a soil community imparts no additional enlightenment regarding the current performance of the soil food web. The presence of a profusion of dauer larvae within a soil is an indication that a system has declined to a less enriched state after a period of enrichment (Ferris \& Bongers, 2009).

Enriched and disturbed environments are indicated by low MI values, whereas environments that are stable are indicated by high MI values. Compared to colonisers, persisters demonstrate a greater sensitivity to pollutants and other disturbances. Consequently, the MI also functions to evaluate the influence of various assortments of contaminants, both identified and unidentified, encompassing their multifaceted interactions with the abiotic and biotic environment.

\section{Plant-parasitic index (PPI)}

The plant-parasitic index (PPI), which is analogous to the MI, is calculated only for plant-feeding nematodes, with the raison d'être for the profusion of these nematodes being contingent on the dynamism of their host plants, which is influenced sequentially by system enrichment (Bongers, 1990; Bongers et al., 1997; Ferris \& Bongers, 2009). The PPI increases with the augmentation of soil fertility, while the MI diminishes (Bongers \& Ferris, 1999). Under particular circumstances, the PPI is inversely related to the MI.

Other indices that form part of the MI family are: the PPI/MI (Bongers \& Korthals, 1995; Bongers et al., 1997); the MI2-5 (Bongers \& Korthals, 1993); the $\sum$ MI (Yeates, 1994); and the $\sum$ MI2-5 (Neher \& Campbell, 1996).

\section{Cp triangles}

$\mathrm{Cp}$ triangles are equilateral triangles that are graphical descriptions of faunal composition. These triangles are accommodated by two enrichment axes (percentage cp 1 and cp 2), and one axis that indicates ecosystem complexity (percentage cp 3 to 5), which is founded on the un-weighted proportions of the nematode fauna within each assemblage (De Goede et al., 1993; Ettema \& Bongers, 1993). The graphical depictions advance the connection that cp classes are indicators of ecosystem function and structure, which are not necessarily associated with each other on a general trajectory (Ferris \& Bongers, 2009). An increase along one of the axes is complemented by a decrease along one of the other axes, owing to each axis of the triangles signifying a proportion of the whole nematode fauna.

The problem with the $\mathrm{cp}$ triangles is that the unweighted data do not provide adequate resolution of changes in the fauna, in addition to the points along the enrichment and structure axes lacking independence (Ferris \& Bongers, 2001; Ferris et al., 2004).

\section{Indicators of ecosystem function}

The advancement of various perceptions, as well as the justification of models and research associated with the improvement of the MI and associated indices, led to the development of a functional guild classification of nematodes, which forms a foundation for the examination and evaluation of ecosystem processes (Bongers \& Bongers, 1998; Bongers \& Ferris, 1999). The existence of such a guild is a dependable indicator of a lack of disturbance, or of recovery from disturbance within a system.

Nematodes that are classified as enrichment opportunists indicate the flow of resources into the soil food web system; furthermore, the occurrence and profusion of organisms higher up in the trophic level indicates the trophic connectance of a system. The two factors mentioned are very important attributes that are provided by the nematode fauna within the soil with regard to the soil environment that is present, and with regard to the resident communities (Ferris \& Bongers, 2009).

Both the enrichment trajectory and the structure trajectory are based on the indicator consequence of functional guilds of nematodes, and are descriptors of the condition of the food web (Ferris \& Bongers, 2009). The trajectories allow for the quantification of the state of the soil food web by means of various indices. These indices are the enrichment index (EI), the structure index (SI) and the channel index (CI). The EI is a measure of the presence of opportunistic bacterivore and fungivore nematodes, whereas the SI is an indicator of the food web state being affected by stress or disturbance and the $\mathrm{CI}$ is an indicator of the predominant decomposition pathways. According to Bongers and Ferris (1999) and Ferris et al. (2009), functional guilds are defined as a matrix of nematode feeding habits, with the biological, ecological and life history characteristics being embodied in the cp classification. Consequently, cp 3 bacterivores (for instance Teratocephalidae or Prismatoloaimidae) comprise the $\mathrm{Ba}_{3}$ functional guild. All nematodes classified as having cp 2 feeding habits are regarded as basal to both the structure and the enrichment trajectories (Ferris \& Bongers, 2009). Enrichment indicators are bacterial feeding cp 1 and fungal feeding cp 2 nematodes, while all nematodes with feeding habits in cp 3 to 5 are considered to be indicators of structure. On the enrichment axis, functional guild indicators are weighted according to growth and metabolic rates or resource consumption, while the structure trajectory is weighted according to sensitivity to disturbance (Ferris \& Bongers, 2001).

\section{Commercial use of nematodes as bio-indicators}

Nematodes have been utilised as environmental bio-monitors for aquatic systems since the 1970s. An example of such an environmental bio-monitor is the nematode Panagrellus redivivus (Linnaeus, 1767) (Goodey, 1945), which has been utilised for the detection of toxin concentrations. The toxins affect moulting, body size and the inhibition or lethality of nematodes. Panagrellus redivivus also presents a rapid bioassay at $10 \%$ less than the cost of a Salmonella bioassay. It has also been used to ascertain the toxic effects of approximately 400 single chemicals (Neher, 2001).

Another commercial use for nematodes in the 1970s was in the nematode:copepod ratio (Amjad \& Gray, 1983). 
Copepods are small, shrimplike crustaceans occurring in seas, lakes and ponds, and they are very important in the food web, since many animals feed on them. The ratio concerned was generally used to monitor the condition of aquatic ecosystems. Nematodes are less sensitive to environmental stress factors and pollution and, consequently, a high nematode:copepod ratio is indicative of pollution and increasing levels of enrichment. However, the ratio is burdened with problems, one of which is that pollution has already transpired by the time that a shift in the ratio becomes obvious. Another problem is that copepods consume nematodes, which leads to an unreliable ratio. Copepod populations are also positively correlated with the size of sand grains, making it almost impossible to determine whether population changes are due to pollution or due to the particle size of the sediment (Neher, 2001).

The nematode Aphelenchus avenae Bastian, 1865, which is used commercially to test for nematicidal activity in soil, feeds on a wide variety of fungi. In agricultural soils, a microorganism population can evolve to utilise the active ingredients in organophosphates and carbamates as a source of carbon for energy, due to the frequent use of such nematicides. High populations of said microbial complexes in the soil can shorten the residual activity of nematicides, from weeks to a few hours, in a phenomenon that is known as accelerated microbial degradation (AMD). When the number of $A$. avenae per sample tested increases dramatically in comparison to that in a control (i.e. in untreated soil), the assumption is that microbial populations that are responsible for AMD are present in the soil (Stirling et al., 1992).

Pattison et al. (2008) developed a minimum set of key soil health indicators for the Australian banana industry aimed at integrating the properties (physical, biological and chemical) of soil. The indicators were also developed to allow banana growers, extension workers and researchers to improve soil health management practices. Biological properties of soil were determined by using the soil nematode community as a bio-indicator of soil health. Various nematode community composition indices were calculated from the nematode populations extracted from the soil. The Shannon-Weiner index was used to determine the diversity of the nematode community present, and dominance was calculated by means of Simpson's index of dominance.

The health of our soils is imperative for the sustainable production of food and fibre. Practices that improve soil health will ultimately lead to improved soil characteristics. Healthy soils created by optimised farm management practices, such as vineyard and orchard floor manipulation, will lead to the long-term cost-effectiveness of farming practices in the future. Healthy soils will add value to properties and benefit countries' food exports. The use of effective biological indicators of soil health, such as nematodes, will provide a building block by which South African grape and fruit producers potentially can measure and improve the health of their soil. The use of nematodes as bio-indicators of soil health cannot be a stand-alone measure for the determination of soil health, but should form an important part of an integrated system of measurements. It can be regarded as the first step in the establishment of key soil health indicators for the deciduous fruit, table grape and wine grape industries in the Western Cape province of South Africa.

\section{LITERATURE CITED}

Alexander, M., 1977. Introduction to soil microbiology. John Wiley \& Sons, Inc., Hoboken, NJ.

Amjad, S. \& Gray, J.S., 1983. Use of nematode-copepod ratio as an index of organic pollution. Mar. Pollut. Bull. 14, 178-181.

Anderson, J.P.E., 1982. Soil respiration. In: American Society of Agronomy, Page, A.L (ed). Methods of soil analysis. Part 2. Chemical and microbiological properties. American Society of Agronomy, Madison, Wisconsin. pp. 831-871.

Angle, J.S., Chaney, R.L. \& Rhee, D., 1993. Bacterial resistance to heavy metals related to extractable and total metal concentrations in soil and media. Soil Biol. Biochem. 25, 1443-1446.

Apsimon, H., Thornton, I., Fyfe, W., Hong, Y., Leggett, J., Nriagu, J.O., Pacyna, J.N., Page, A.L., Price, R., Skinner, B., Steinnes, E. \& Yim, W., 1990. Anthropogenically induced global change. Report of Working Group Three, IUGS Workshop on Global Change in Past and Present. Palaeogeogr. Palaeocl. 82, 97-111.

Bending, G.D., Putland, C. \& Rayns, F., 2000. Changes in microbial community metabolism and labile organic matter fractions as early indicators of the impact of management on soil biological quality. Biol. Fert. Soils 31, 78-84.

Bengtsson, J. \& Tranvik, L., 1989. Critical metal concentrations for forest soil invertebrates. Water Air Soil Poll. 30, 87-108.

Bird, A.F. \& Ryder, M.H., 1993. Feeding of the nematode Acrobeloides nanus on bacteria. J. Nematol. 25, 493-499.

Bongers, T., 1990. The maturity index: An ecological measure of environmental disturbances based on nematode species composition. Oecologia 83, 14-19.

Bongers, T. \& Bongers, M., 1998. Functional diversity of nematodes. Appl. Soil Ecol. 10, 239-251.

Bongers, T. \& Ferris, H., 1999. Nematode community structure as a bioindicator in environmental monitoring. Trends Ecol. Evol. 14, 224-228.

Bongers, T. \& Korthals, G., 1993. The maturity index, an instrument to monitor changes in the nematode community structure. Summaries of the 45th International Symposium on Crop Protection, May 4, Ghent, Belgium, 80 .

Bongers, T. \& Korthals, G., 1995. The behavior of MI and PPI under enriched conditions. Nematologica 41, 286.

Bongers, T., Van der Meulen, H. \& Korthals, G., 1997. Inverse relationship between nematode maturity index and plant parasite index under enriched nutrient conditions. Appl. Soil Ecol. 6, 195-199.

Brendecke, J.W., Axelson, R.D. \& Pepper, I.L., 1993. Soil microbial activity as an indicator of soil fertility: Long-term effects of municipal sewage sludge on an arid soil. Soil Biol. Biochem. 25, 751-758.

Burgess, S., Campbell, C.D., Smith, C. \& Killham, K., 2001. Can management alter impacts on microbial communities in agricultural soils which have been treated long-term with waste-water sludge? Poster presented at the $9^{\text {th }}$ Int. Symp. on Microbial Ecology, Amsterdam.

Chander, K. \& Brookes, P.C., 1993. Residual effects of zinc, copper, and nickel in sewage sludge on microbial biomass in a sandy loam. Soil Biol. Biochem. 25, 1231-1239.

Chantanao, A. \& Jensen, H.J., 1969. Saprozoic nematodes as carriers and disseminators of plant pathogenic bacteria. J. Nematol. 1, 216-218.

Darbyshire, J.F., 1994. Soil protozoa. CAB International, Wallingford, England. 
De Goede, R.G.M., Bongers, T. \& Ettema, C.H., 1993. Graphical presentation and interpretation of nematode community structure: C-P triangles. Int. S. Crop. 58, 743-750.

Dick, R.P., 1997. Soil enzyme activities as integrative indicators of soil health. In: Pankhurst, C.E., Doube, B.M. \& Gupta, V.V.S.R. (eds). Biological indicators of soil health. CAB International, Wallingford, England. pp. 121156 .

Doran, J.W. \& Safley, M., 1997. Defining and assessing soil health and sustainable productivity. In: Pankhurst, C.E., Doube, B.M. \& Gupta V.V.S.R. (eds). Biological indicators of soil health. CAB International, Wallingford, England. pp. 1-28.

Doran, J.W., Sarrantonio, M. \& Liebig, M.A., 1996. Soil health and sustainability. In: Sparks, D.L. (ed). Advances in Agronomy. Academic Press, San Diego, California. pp. 1-54

Doube, B.M. \& Schmidt, O., 1997. Can the abundance or activity of soil macrofauna be used to indicate the biological health of soils? In: Pankhurst, C.E., Doube, B.M. \& Gupta, V.V.S.R. (eds). Biological indicators of soil health. CAB International, Wallingford, England. pp. 265-295.

Edwards, C.A. \& Bohlen, P.J., 1996. Biology and ecology of earthworms. Chapman and Hall, London, United Kingdom.

Elliot, E.T., 1997. Rationale for developing bioindicators of soil health. In: Pankhurst, C.E., Doube, B.M. \& Gupta, V.V.S.R. (eds). Biological indicators of soil health. CAB International. Wallingford, England. pp. 49-78.

Ettema, C.H. \& Bongers, T., 1993. Characterization of nematode colonization and succession in disturbed soil using the maturity index. Biol. Fert. Soils 16, 79-85.

Ferris, H. \& Bongers, T., 2001. A framework for soil food web diagnostics: Extension of the nematode faunal analysis concept. Appl. Soil Ecol. 18, 13-29.

Ferris, H. \& Bongers, T., 2006. Nematode indicators of organic enrichment. J. Nematol. 38, 3-12.

Ferris, H. \& Bongers, T., 2009. Indices developed specifically for analysis of nematode assemblages. In: Wilson, M.J. \& Kakouli-Duarte, T. (eds). Nematodes as environmental indicators. CAB International, Wallingford, England. pp. 124-145.

Ferris, H., Bongers, T. \& De Goede, R.G.M., 2004. Nematode faunal analyses to assess food web enrichment and connectance. In: Cook, R.C. \& Hunt, D.J. (eds). Proceedings of the 4th International Congress of Nematology, 8-13 June 2002, Tenerife, Spain. pp. 503 - 510.

Framptom, G.K., 1999. Spatial variation in non-target effects of the insecticides chlopyrifos, cypermethrin and pirimicarb on Collembola in winter wheat. Pestic. Sci. 55, 875-886.

Freckman, D.W., 1988. Bacterivorous nematodes and organic-matter decomposition. Agr. Ecosyst. Environ. 24, 195-217.

Freckman, D.W. \& Caswell, E.P., 1985. The ecology of nematodes in agroecosystems. Annu. Rev. Phytopathol. 23, 275-296.

Frostegård, Å., Tunlid, A. \& Bååth, E., 1996. Changes in microbial community structure during long-term incubation in two soils experimentally contaminated with metals. Soil Biol. Biochem. 28, 55-63.

Gugino, B.K., Idowu, O.J., Schindelbeck, R.R., Van Es, H.M., Wolfe, D.W., Moebius-Clune, B.N., Thies, J.E. \& Abawi, G.S., 2009 ( $2^{\text {nd }}$ ed). Cornell soil health assessment training manual. Cornell University, Geneva, N.Y.

Gupta, V.V.S.R. \& Germida, J.J., 1989. Influence of bacterial-amoebal interactions on sulfur transformations in soil. Soil Biol. Biochem. 21, $787-$ 791.
Gupta, V.V.S.R. \& Yeates, G.W., 1997. Soil microfauna as bioindicators of soil health. In: Pankhurst, C.E., Doube, B.M. \& Gupta, V.V.S.R. (eds). Biological indicators of soil health. CAB International, Wallingford, England. pp. 201-233.

Guven, K., Duce, J.A. \& De Pomerai, D.I., 1994. Evaluation of a stressinducible transgenic nematode strain for rapid aquatic toxicity testing. Aquat. Toxicol. 29, 119-137.

Guven, K., Power, R.S., Avramides, S., Allender, R. \& De Pomerai, D.I. 1999. The toxicity of dithiocarbamate fungicides to soil nematodes, assessed using a stress-inducible transgenic strain of Caenorhabditis elegans. J. Biochem. Mol. Toxic. 13, 324-333.

Harden, T., Joergensen, R.G., Meyer, B. \& Wolters, V., 1993. Soil microbial biomass estimated by fumigation-extraction and substrate-induced respiration in two pesticide-treated soils. Soil Biol. Biochem. 25, 679-683.

Hashmi, G., Hashmi, S., Selvan, S., Grewal, P. \& Gaugler, R., 1997. Polymorphism in heat shock protein gene (hsp70) in entomopathogenic nematodes (Rhabditida). J. Therm. Biol. 22, 143-149.

Hendrix, P.F., 1995. Earthworm ecology and biogeography in North America. CRC Press, Boca Raton, Florida, USA.

Henkinet, R., Couteaux, M.M., Billes, G., Bottner, P. \& Palka, L., 1990. Acceleration of carbon turnover and stimulation of the priming effect by predation in forest humus. Soil Biol. Biochem. 22, 555-561.

Hill, M.O., 1973. Diversity and evenness: A unifying notation and its consequences. Ecology 54, 427-432.

Hornby, D. \& Bateman, G.L., 1997. Potential use of plant root pathogens as bioindicators of soil health. In: Pankhurst, C.E., Doube, B.M. \& Gupta, V.V.S.R. (eds). Biological indicators of soil health. CAB International, Wallingford, England. pp. 179-200.

Hussey, R.S. \& Roncadori, R.W., 1981. Influence of Aphelenchus avenae on vesicular-arbuscular endomycorrhizal growth response in cotton. J. Nematol. 13, 48-52.

Insam, H., 1990. Are the soil microbial biomass and basal respiration governed by climatic regime? Soil Biol. Biochem. 22, 525-532.

Jenkinson, D.S. \& Ladd, J.N., 1981. Microbial biomass in soil: Measurement and turnover. In: Paul, E.A. \& Ladd, J.N. (eds). Soil biochemistry. Marcel Dekker Inc., New York, USA. pp. 415-471.

Kammenga, J.E., Arts, M.S.J. \& Oude-Breuil, W.J.M., 1998. HSP60 as a potential biomarker of toxic stress in the nematode Plectus acuminatus. Archi. Environ. Con. Tox. 34, 253-258.

Kammenga, J.E., Dallinger, R., Donker, M.H., Kohler, H.R., Simonsen, V., Triebskorn, R. \& Weeks, J.M., 2000. Biomarkers in terrestrial invertebrates for ecotoxilogical soil risk management. Rev. Environ. Contam. T. 164, 93147.

Kang, B.T., Akinnifesi, F.K. \& Pleysier, J.L., 1994. Effect of agroforestry woody species on earthworm activity and physiochemical properties of worm casts. Biol. Fert. Soils 18, 192-199.

Lee, K.E., 1985. Earthworms: Their ecology and relationships with soils and land use. Academic Press Inc., Waltham, USA.

Linden, D.R., Hendrix, P.F., Coleman, D.C. \& Van Vleet, P., 1994. Faunal indicators of soil quality. In: Doran, J.W., Coleman, D.C., Bezdicek D.F. \& Stewart, B.A. (eds). Defining soil quality for a sustainable environment. Soil Science Society of Ameirica, Special Publication no. 35, pp. 91 - 106.

Martens, R., 1995. Current methods for measuring microbial biomass C in soil: Potentials and limitations. Biol. Fert. Soils 19, 87-99.

Neher, D.A., 2001. Role of nematodes in soil health and their use as indicators. J. Nematol. 33, 161-168. 
Neher, D.A. \& Campbell, C.L., 1996. Sampling for regional monitoring of nematode communities in agricultural soils. J. Nematol. 28, 196-208.

Nielsen, M.N. \& Winding, A., 2002. Microorganisms as indicators of soil health. Technical Report No. 388. National Environmental Research Institute, Denmark.

Norton, D.C., 1978. Ecology of plant-parasitic nematodes. WileyInterscience, New York, USA.

Odum, E.P., 1985. Trends expected in stressed ecosystems. Bioscience 35, 419-422.

Old, K.M., 1986. Mycophagous soil amoebae: Their biology and significance in the ecology of soil-borne plant pathogens. Progress in Protistology 1, 163-194.

Pankhurst, C.E., 1994. Biological indicators of soil health and sustainable productivity. In: Greenland, D.J. \& Szabolcs, I. (eds). Soil resilience and sustainable land use. CAB International, Wallingford, England. pp. 331351 .

Pankhurst, C.E., Doube, B.M. \& Gupta, V.V.S.R., 1997. Biological indicators of soil health: Synthesis. In: Pankhurst, C.E., Doube, B.M. \& Gupta, V.V.S.R. (eds). Biological indicators of soil health. CAB Inernational, Wallingford, England. pp. 419-435.

Pattison, A.B., Moody, P.W., Badcock, K.A., Smith, L.J., Armour, J.A., Rasiah, V., Cobon, J.A., Gulino, L.M. \& Mayer, R., 2008. Development of key soil health indicators for the Australian banana industry. Appl. Soil Ecol. 40, 155-164.

Pielou, E.C., 1966. The measurement of diversity in different types of biological collections. J. Theor. Biol. 13, 131-144.

Powlson, D.S., Brookes, P.C. \& Christensen, B.T., 1987. Measurement of soil microbial biomass provides an early indication of changes in total soil organic matter due to straw incorporation. Soil Biol. Biochem. 19, 159-164.

Powlson, D.S. \& Jenkinson, D.S., 1981. A comparison of the organic matter, biomass, adenosine triphosphate and mineralizable nitrogen contents of ploughed and direct-drilled soils. J. Agr. Sci. 97, 713-721.

Ritz, K. \& Trudgill, D.L., 1999. Utility of nematode community analysis as an integrated measure of the functional state of soils: Perspectives and challenges - Discussion paper. Plant Soil 212, 1-11.

Roper, M.M. \& Ophel-Keller, K.M., 1997. Soil microflora as bioindicators of soil health. In: Pankhurst, C.E., Doube, B.M. \& Gupta, V.V.S.R. (eds). Biological indicators of soil health. CAB International, Wallingford, England. pp. 157-177.

Rowell, M.J. \& Florence, L.Z., 1993. Characteristics associated with differences between undisturbed and industrially-disturbed soils. Soil Biol. Biochem. 25, 1499-1511.

Ruf, A., 1998. A maturity index for predatory soil mites (Mesostigmata: Gamasina) as an indicator of environmental impacts of pollution on forest soils. Appl. Soil Ecol. 9, 447-452.

Samoiloff, M.R., 1987. Nematodes as indicators of toxic environmental contaminants. In: Veech, J.A. \& Dickson, D.W. (eds). Vistas in nematology: A commemoration of the 25th annual meeting of The Society of Nematologists. Society of Nematologists, Madison, USA, pp. 433 - 439.

Shannon, C.E. \& Weaver, W., 1949. The mathematical theory of Communication. University of Illinois Press, Urbana, USA

Simpson, E.H., 1951. The interpretation of interaction in contingency tables. J. Roy. Stat. Soc. B 13, 238-241.

Sparling, G.P., 1997. Soil microbial biomass, activity and nutrient cycling as indicators of soil health. In: Pankhurst, C.E., Doube, B.M. \& Gupta, V.V.S.R. (eds). Biological indicators of soil health. CAB International, Wallingford, England. pp. 97-119.
Sparling, G.P. \& Ross, D.J., 1993. Biochemical methods to estimate soil microbial biomass: Current developments and applications. In: Mulangoy, K. \& Merckx, R. (eds.). Soil organic matter dynamics and sustainability of tropical agriculture. John Wiley \& Sons, Inc., Hoboken, New Jersey, USA. pp. 21-37.

Speir, T.W., Kettles, H.A., Parshotam, A., Searle, P.L. \& Vlaar, L.N.C., 1995. A simple kinetic approach to derive the ecological dose value, $\mathrm{ED}_{50}$, for the assessment of $\mathrm{Cr}$ (VI) toxicity to soil biological properties. Soil Biol. Biochem. 27, 801-810.

Stirling, A.M., Stirling, G.R. \& MacRae, I.C., 1992. Microbial degradation of fenamiphos after repeated application to a tomato-growing soil. Nematologica 38, 245-254.

Stout, J.D. \& Heal, O.W., 1967. Protozoa. In: Burges, A. \& Raw, F. (eds). Soil biology. Academic Press Inc., Waltham, USA. pp. 149-195.

Swift, M.J., Heal, O.W. \& Anderson, J.M., 1979. In: Anderson, D.J., GreigSmith, P. \& Pitelka, F.A. (eds). Studies in ecology volume 5. University of California Press, Berkley and Los Angeles, USA

Tian, G., Brussaard, L. \& Kang, B.T., 1993. Biological effects of plant residues with contrasting chemical compositions under humid tropical conditions: Effects on soil fauna. Soil Biol. Biochem. 25, 731-737.

Turco, R.F., Kennedy, A.C. \& Jawson, M.D., 1994. Microbial indicators of soil quality. In: Doran, J.W., Coleman, D.C., Bezdicek, D.F. \& Stewart, B.A. (eds). Soil Science Society of America, Special Publication no. 35. pp. 73-90.

Valsecchi, G., Gigliotti, C. \& Farini, A., 1995. Microbial biomass, activity, and organic matter accumulation in soils contaminated with heavy metals. Biol. Fert. Soils 20, 253-259.

Van Bruggen, A.H.C. \& Semenov, A.M., 2000. In search of biological indicators of soil health and disease suppression. Appl. Soil Ecol. 15, 13-24.

Van Straalen, N.M., 1997. Community structure of soil arthropods as bioindicator of soil health. In: Pankhurst, C.E., Doube, B.M. \& Gupta, V.V.S.R. (eds). Biological indicators of soil health. CAB International, Wallingford, England. pp. 235-264.

Van Straalen, N.M. \& Verhoef, H.A., 1997. The development of a bioindicator system for soil acidity based on arthropod $\mathrm{pH}$ preferences. J. Appl. Ecol. 34, 217-232.

Weiner, E.S.C. \& Simpson, J.A., 1989. In: Weiner, E.S.C. (ed). The Oxford English Dictionary. Oxford University Press, New York, USA.

Westcott, S.W. \& Barker, K.R., 1976. Interaction of Acrobeloides buetschlii and Rhizobium leguminosarum on Wanda pea. Phytopathology 66, 468-472.

Yeates, G.W., 1981. Nematode populations in relation to soil environmental factors: A review. Pedobiologia 22, 312-338.

Yeates, G.W., 1994. Modification and qualification of the nematode maturity index. Pedobiologia 38, 97-101.

Yeates, G.W., 2003. Nematodes as soil indicators: Functional and biodiversity aspects. Biol. Fert. Soils 37, 199-210.

Yeates, G.W., Bongers, T., Freckman, D.W. \& Georgieva, S.S., 1993. Feeding habits in soil nematode families and genera - An outline for soil ecologists. J. Nematol. 25, 315-331.

Yeates, G.W. \& Coleman, D.C., 1982. Nematodes in decomposition. In: Freckman, D.W. (ed). Nematodes in soil ecosystems. University of Texas Press, Austin, Texas, USA. pp. 55-80.

Yeates, G.W., Orchard, V.A., Speir, T.W., Hunt, J.L. \& Hermans, M.C.C., 1994. Impact of pasture contamination by copper, chromium, arsenic timber preservative on soil biological activity. Biol. Fert. Soils 18, 200-208. 